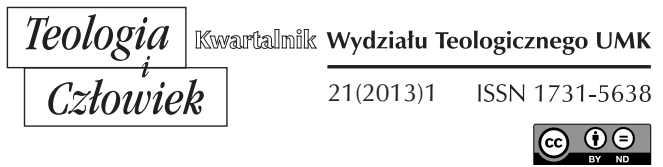

KS. DARIUSZ IWAŃSKI*

TORUŃ

\title{
KSIĘGA HENOCHA - STAROŻYTNY APOKRYF W ŚWIETLE WSPÓŁCZESNEJ WIEDZY
}

DOI: http://dx.doi.org/10.12775/TiCz.2013.007

Księga Henocha (Corpus Henochicum, 1 Hen) to jeden z najważniejszych dokumentów z kręgu tzw. literatury międzytestamentalnej. Jest ona dość skomplikowanym tworem literackim, na który składają się pisma powstałe w różnych okresach judaizmu Drugiej Świątyni. Owe pisma reprezentują "różne tendencje teologiczne, czasem nawet przeciwstawne" ${ }^{\prime 1}$. Być może dlatego dzieło to ostatecznie nie znalazło się w kanonie Biblii Hebrajskiej, ani Biblii chrześcijańskiej. Niemniej jednak trudno przecenić jego znaczenie dla wielu Żydów Drugiej Świątyni oraz pierwszych chrześcijan. Można bez wahania stwierdzić, że Księga miała ogromny wpływ na myślenie i wrażliwość religijną judaizmu u progu ery chrześcijańskiej, a później była także inspiracją dla wielu chrześcijan pierwszych wieków chrześcijaństwa. Świat symboliki Księgi Henocha odbija

* Ks. dr hab. Dariusz Iwański, jest kapłanem diecezji toruńskiej. Odbył specjalistyczne studia biblijne w Papieskim Instytucie Biblijnym (Biblicum) w Rzymie uwieńczone licencjatem nauk biblijnych. Doktorat $\mathrm{z}$ teologii biblijnej obronił na Papieskim Uniwersytecie Gregoriańskim w Rzymie. Od roku 2008 jest wykładowcą na Wydziale Teologicznym UMK w Toruniu.

${ }^{1}$ R. Rubinkiewicz, Eschatologia Hen 9-11 a Nowy Testament, Lublin 1984, s. 11. 
się echem na przykład w Księdze Daniela, a później także w Apokalipsie św. Jana.

Dla powyższych racji rzeczona Księga stała się dla współczesnych badaczy ważnym źródłem analiz nad tłem religijnym oraz społecznym, w jakim dojrzewały najmłodsze Księgi Starego Testamentu oraz literatura nowotestamentalna. Naukowcy coraz bardziej przekonują się, że studia nad literaturą międzytestamentalną mogą dać szerszy ogląd judaizmu Drugiej Świątyni, a także pomóc w odtworzeniu procesu dojrzewania myśli teologicznych ważnych dla judaizmu i chrześcijaństwa.

Żeby zrozumieć fenomen Księgi Henocha, warto przyjrzeć się stanowi wiedzy na jej temat. Niniejsze studium jest właśnie prezentacją współczesnej wiedzy dotyczącej powstania, Vorlage i datacji Corpus Henochicum.

\section{OD STAROŻYTNOŚCl DO CZASÓW NOWOŻYTNYCH}

Księga Henocha dość wcześnie zaczęła być w obiegu wśród Kościołów chrześcijańskich i to zarówno na Wschodzie, jak i na Zachodzie ${ }^{2}$. Pierwsze nawiązania do niej spotykamy już w Liście Judy oraz u kilku pisarzy wczesnochrześcijańskich ${ }^{3}$. Orygenes wspomina o Księdze w kilku swych dziełach ${ }^{4}$, ale bodaj najbardziej interesująca jest wzmianka o niej przy okazji polemiki z Celsusem (Cels. 5,52-55; ok. 250 po Chr.). Autor przywołuje tam m.in. zarzuty Celsusa pod adresem Chrystusa. Adwersarz Orygenesa dla potrzeb swych wywodów zaproponować miał hipotetycz-

${ }^{2}$ Por. B.A. Pearson, Enoch in Egypt, w: R.A. Argall, B.A. Bow, R.A. Werline (red.), For a Later Generation. The Transformation of Tradition in Israel, Early Judaism and Early Christianity, Harrisburg 2000, s. 216-231 [218-220].

${ }^{3}$ Zobacz obszerną listę cytacji w tym względzie: M. Black (red.), Apocalypsis Henochi Graece (PVTG 3; Leiden 1970), s. 10-14. Na temat aniołów i ich misji w myśli ojców Kościoła zob. J. Daniélou, Les anges et leur mission d'après les Pères de l'Église, Paris 1952. J.R. Davila, (How) Can We Tell if a Greek Apocryphon or Pseudepigraphon Has Been Translated From Hebrew or Aramaic?, JSP 15.1 (2005), s. 3-61 [10], zauważa, że cytat z 1 Hen 1,9 w Liście Judy 14-15 wskazuje wyraźnie na istnienie greckiego tłumaczenia Księgi Czuwających w czasie, kiedy powstawał ów List Judy. Według niego, było to najprawdopodobniej dzieło, które wyszło spod pióra żydowskiego tłumacza władającego językiem greckim.

${ }^{4}$ Por. J.C. VanderKam, 1 Enoch, Enochic Motifs, and Enoch in Early Christian Literature, w: J.C. VanderKam, W. Adler (red.), The Jewish Apocalyptic Heritage in Early Christianity, Minneapolis 1996, s. 34-101 [54]. 
ne założenie, że Jezus był faktycznie jakimś aniołem. Następnie twierdził, że gdyby wówczas zapytać samych chrześcijan, czy był on (Chrystus) pierwszym i jedynym, który zstąpił na ziemię, a oni odpowiedzieliby twierdząco, to przecież mówiliby kłamstwa i sami by sobie zaprzeczali. Celsus twierdził bowiem, że zgodnie z tym czego nauczali chrześcijanie, przed Chrystusem było już sześćdziesięciu, bądź siedemdziesięciu innych, którzy stali się złymi aniołami, a następnie skuci łańcuchami zostali strąceni do otchłani. Orygenes odpiera ten zarzut, m.in., dyskredytując źródło, z którego zaczerpnął Celsus. Oczywiście, źródłem tym były księgi, które występowały pod wspólnym tytułem „Henoch”5. Według Orygenesa Celsus nie tylko nie czytał tych ksiąg, lecz także źle zrozumiał ich treść, którą ktoś mu zreferował. Nade wszystko jednak nie pojął, że generalnie wśród Kościołów chrześcijańskich Księga Henocha, nie cieszyła

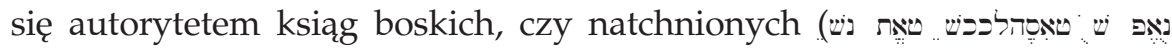

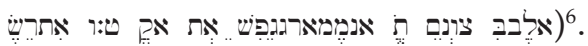

Hieronim sytuował Księgę Henocha wśród ksiąg apokryficznych (por. Comm. Tit. 1,2; Vir. ill. 4), przez co rozumiał księgi spoza kanonu. Augustyn również traktował ją, jako dzieło apokryficzne, ale nie odmawiał jej natchnionego charakteru. Dowodem na to, iż było to pismo natchnione, miał być fakt, że jego echo znalazło się w Liście Judy. Jednocześnie, Augustyn zastrzegał, że Księga Henocha nie jest akceptowana wśród chrześcijan, jako księga kanoniczna. Na pytanie, dlaczego tak jest, odpowiadał dość enigmatycznie, mówiąc, że starożytni, którzy mogli ją za taką uznać nie zrobili tego, a więc należy utrzymać status quo (por. Civ. 15,23; 18,38). O wiele bardziej radykalny był autor Konstytucji Apostolskich, który potępił omawiane dzieło, tak zresztą, jak i inne księgi apokryficzne, uznając je za zgubne i wrogie względem prawdy ${ }^{7}$.

Kościół etiopski nie podzielił tego radykalizmu i włączył 1 Hen do swego kanonu ksiąg natchnionych ${ }^{8}$. M.A. Knibb uważa, że w ślad za

${ }^{5}$ J.C. VanderKam, 1 Enoch, Enochic Motifs, and Enoch in Early Christian Literature, s. 58-59, zwrócił uwagę, że Orygenes zamiennie używa liczby pojedynczej i mnogiej w odniesieniu do Henocha („księga” i „księgi”).

${ }^{6}$ Por. C. Blanc (red.), Origène, commentaire sur Saint Jean 2 (SC 157; Paris 1970) 297.

7 Por. R.H. Charles, The Book of Enoch or 1 Enoch, Oxford ${ }^{2} 1912$, s. 1xxxv. xci-xcii.

8 Por. R.W. Cowley, The Biblical Canon of the Ethiopian Orthodox Church Today, OS 23 (1974), s. 318-323. G. E. Ladd, The Kingdom of God in the Jewish Apocryphal Literature, 328-329, stwierdza, że wszyscy mamy dług wobec Kościoła Abisyńskiego za przechowanie Księgi Henocha w całości. 
tym poszło tłumaczenie dzieła (razem z księgami Pisma św.) na język etiopski. Było to $w$ okresie po przyjęciu chrześcijaństwa, jako oficjalnej religii w Królestwie Aksum, co nastąpiło - mniej więcej - w połowie czwartego wieku po Chrystusie. Prawdopodobnie praca nad tłumaczeniem trwała etapami. Można przyjąć, że ostateczne tłumaczenie zostało ukończone około piątego lub szóstego wieku po Chrystusie ${ }^{9}$. Niestety, nie dysponujemy oryginalnymi tłumaczeniami z tego okresu. Najstarszy zachowany manuskrypt etiopski, zawierający fragmenty omawianego dzieła, pochodzi z około XV wieku. Chodzi o dzieło Mashafa Milad (Księga Bożego Narodzenia) przypisywane wybitnemu królowi etiopskiemu Zara Yakobowi (1438-1468). Zawiera ono długie wyjątki z 1 Hen (zwłaszcza z Księgi Przypowieści) przetykane komentarzami ${ }^{10}$.

W Europie, od średniowiecza do czasów nowożytnych, Księga Henocha uchodziła za zaginioną. Niekiedy tylko pojawiały się sensacyjne, choć niepotwierdzone, informacje o tym, że dzieło odnalazło się w jakichś niezwykłych okolicznościach. Dla przykładu, pod koniec XV wieku, Johann Reuchlin, z wielkim entuzjazmem odnotował, że Giovanni Pico della Mirandola (1463-1494) rzekomo nabył egzemplarz rzeczonej Księgi ${ }^{11}$. Miał się tym publicznie chwalić sam zainteresowany - nie kryjąc, jednocześnie, że słono zapłacił za ten kaprys. Pico Della Mirandola, jako wybitny przedstawiciel włoskiego Odrodzenia, cieszył się wielką estymą wśród sobie współczesnych. Zapewne więc, bardziej niż ktokolwiek pasował do wymyślonego scenariusza o sensacyjnie odnalezionym tekście Księgi Henocha. Kilkanaście lat później (w 1517 r.), ten sam Johann Reuchlin zdawał się już nie pamiętać o wzmiankowanym wcześniej zakupie. Pisał bowiem o Księdze Henocha, że choć jej fragmenty były często cytowane $\mathrm{w}$ czasach starożytnych przez ludzi cieszących się autorytetem, to zaginęły w czasach jemu współczesnych ${ }^{12}$.

N. Schmidt uważa, jednak, że zakup, o którym wspomina Reuchlin, mógł rzeczywiście być zrobiony. Chodziło być może o hebrajską

9 Por. M.A. Knibb, Christian Adoption and Transmission of Jewish Pseudepigrapha: the Case of 1 Enoch, JSJ 32 (2001), s. 396-415 [403]. Por. także E. Ullendorff, Ethiopia and the Bible: The Schweich Lectures of the British Academy 1967, Oxford 1968, s. 31-72.

${ }_{10}$ Por. M.A. Knibb, Christian Adoption and Transmission of Jewish Pseudepigrapha, 413-414.

${ }^{11}$ Por. N. Schmidt, Traces of the Early Acquaintance in Europe with the Book of Enoch, JAOS 42 (1922), s. 45.

${ }^{12}$ Por. tamże. 
kopię Księgi Henocha, chociaż nie można także wykluczyć, że była to kopia etiopska. Niestety, według niego, nie da się tego dowieść z całą pewnością. Dość powiedzieć, że pod koniec średniowiecza wspomniane wyżej informacje wzbudziły dużą koniunkturę na literaturę henochicką. To z kolei wzmogło działalność oszustów, którzy produkowali różne pseudodzieła, sprzedając je później, jako rzekomo należące do Corpus Henochicum ${ }^{13}$.

Około roku 1592, Józef Justus Scaliger (1540-1609), rozpoznał w tekście bizantyńskiego historyka Georgiusa Syncellusa, fragmenty Księgi Henocha $(6,1-10,14 ; 15,8-16,1)$. Chodziło o dzieło pt. Thesaurus Temporum z początku dziewiątego wieku po Chrystusie. Dzieło to było pomyślane, jako chronografia wszechczasów - począwszy od stworzenia świata, aż do roku 284 po Chr. Jako jednym ze źródeł Syncellus, posłużył się tam właśnie Księgą Henocha ${ }^{14}$. Scaliger, jednak bynajmniej, nie ekscytował się swoim odkryciem. Jako gorliwy protestant nie miał wielkiego szacunku dla literatury spoza kanonu. Być może dlatego w ciągu następnego stulecia nie wydarzyło się nic przełomowego w kwestii zaginionej Księgi Henocha, chociaż wydaje się, że historia mogłaby się potoczyć inaczej, gdyby nie zignorowano tego ważnego odkrycia.

Pierre Gassendi (1592-1655), w dziele poświęconym życiu swego przyjaciela Nicolasa - Claude'a Fabri de Peiresca (Viri Illustris Nicolai Claudii Fabricii de Peiresc Senatoris Aquisextiensis Vita, Paris 1641), wspomina o pewnym kapucynie, Aegidiusie Lochiensis, który spędził siedem lat $\mathrm{w}$ Egipcie, studiując języki orientalne. Po powrocie, miał on opowiadać Peirescowi, że w Aleksandrii zetknął się dziełem pt. Mazhapha Einok, czyli Proroctwo Henocha. Księga ta zawierała proroctwo odnoszące się do wydarzeń, które miały nastąpić przed końcem świata. Była ona napisana w języku Etiopczyków bądź Abisyńczyków. Peiresc miał być ponoć tak podekscytowany tą wiadomością, że za wszelką cenę zapragnął nabyć dla siebie kopię tego dzieła i pragnienie to rzeczywiście się ziściło. Dziś wiadomo, że zakupione dzieło zawierało autentyczny tekst etiopski Księgi Henocha. Schmidt zwraca jednak uwagę, że wśród badaczy współczesnych Peirescowi, panowało przekonanie, że nabywca

${ }^{13}$ Por. tamże, s. 47.

14 J. T. Milik, The Books of Enoch: Aramaic Fragments of Qumran Cave 4, Oxford 1976, s. 5, twierdzi, że Syncellus nie miał bezpośredniego dostępu do Księgi Henocha, ale znał ją z dzieł aleksandryjskich historyków Pandorusa oraz Annianusa (z ok. 400 r. po Chr.). 
został oszukany, bo sprzedano mu jakiś falsyfikat. Ostatecznie Księga, która była niegdyś w posiadaniu Peiresca znalazła się w Bibliotece Mazarin w Paryżu. W 1683 r. pruski badacz Ludolf Hiob postanowił zbadać autentyczność tego dzieła. Wydaje się jednak, że czynił to jedynie dla potwierdzenia swej uprzednio przyjętej tezy, o nieautentyczności Księgi. Szybko ogłosił swoją negatywną ocenę - odmawiając dziełu prawa do bycia Księgą Henocha ${ }^{15}$.

Wreszcie, w roku 1773, szkocki podróżnik James Bruce wrócił do Europy z podróży po Abisynii. Wśród pamiątek, które przywiózł ze sobą były m.in. trzy etiopskie manuskrypty, których treść jest dzisiaj znana, jako $1 \mathrm{Hen}^{16}$. Dwa z nich znalazły swe miejsce w Bodleian Library w Oxfordzie, zaś trzeci sprezentowano królowi Ludwikowi XV. Ten ostatni znajduje się obecnie w Bibliotece Narodowej w Paryżu. Oznaczono je odpowiednio następującymi symbolami: Bodl MS 4, Bodl MS 5 oraz Paris $32^{17}$.

Manuskrypty przywiezione przez Bruce'a musiały jednak jeszcze długo czekać na to, aby się nimi zainteresowano. Przełom nastąpił dopiero, gdy w roku 1800 (po dwudziestu siedmiu latach!) słynny orientalista Sylwester de Sacy, przetłumaczył na łacinę trzy pierwsze rozdziały oraz kilka początkowych wersów innych rozdziałów omawianej Księgi. Rok później niemiecki uczony F. T. Rink dokonał przekładu tego łacińskiego

${ }_{15}$ Por. N. Schmidt, Traces of the Early Acquaintance in Europe with the Book of Enoch, s. 51.

${ }^{16}$ Por. M.J. Davidson, Angels at Qumran. A Comparative Study of 1 Enoch 1-36, 72-108 and Sectarian Writings from Qumran, Sheffield 1992, s. 18. Por. też G. E. Ladd, The Kingdom of God in the Jewish Apocryphal Literature, BSac 109 (1952), s. 318-331 [328-329].

${ }_{17}$ Por. M.A. Knibb, The Ethiopic Book of Enoch. A New Edition in the Light of the Aramaic Dead Sea Fragments, t. II, Oxford 1978, s. 1. Odnośnie do tego, gdzie złożono rzeczone manuskrypty J.E.H. Thomson, Apocalyptic Literature, w: J. Orr (red.), The International Standard Bible Encyclopedia, t. V, Grand Rapids 1939, s. 1-164, prezentuje nieco inną wizję. Mówi on mianowicie, że jeden z tych nich zatrzymał Bruce w Kinnaird House [w swej rodzinnej posiadłości w Szkocji], drugi oddał do the Bodleian Library w Oxfordzie, a trzeci dał do Biblioteki Królewskiej w Paryżu. J. McClintock, Enoch, Book of, w: Cyclopaedia of Biblical, Theological, and Ecclesiastical Literature, t. XII, New York 1870, s. 3-225, cytował słowa samego Bruca: "Amongst the articles I consigned to the library at Paris was a very beautiful and magnificent copy [Ludolf had commented caustically on such waste of effort in the Peiresc manuscript] of the prophecies of Enoch in large quarto. Another is amongst the books of Scripture which I brought home, standing immediately before the Book of Job, which is its proper place in the Abyssinian Canon; and a third copy I have presented to the Bodleian Library at Oxford". 
tekstu na swój język ojczysty. Potem znowu zapadła cisza na kolejnych dwadzieścia lat. Wreszcie, w roku 1821 Richard Laurence, arcybiskup Cashel, opublikował pierwsze angielskie tłumaczenie manuskryptu Bodl MS 4, w książce pt. The Book of Enoch, an Apocryphal Production, Now First Translated, From the Ethiopic Ms. in the Bodleian Library (Oxford 1821). W 1838 roku ukazała się pierwsza edycja etiopskiego tekstu Henocha, którą również przygotował Laurence (Libri Enoch prophetae versio aethiopica [Oxford 1838] $)^{18}$. W wieku XIX przywieziono do Europy więcej manuskryptów. W oparciu o pięć z nich, A. Dillman przygotował i wydał wreszcie pierwszą krytyczną edycję etiopskiego tekstu Księgi Henocha: Liber Henoch Aethiopice (Leipzig 1851). Dwa lata później, w roku 1853, Dillman wydał drukiem tłumaczenie i komentarz do Księgi Henocha ${ }^{19}$.

Odkrycie greckiej wersji tekstu w Akhmim (Panopolis) na przełomie lat 1886/1887 dostarczyło nowego impulsu dla dalszych studiów nad Henochem. Mowa tu o pochodzącym z piątego lub szóstego wieku po Chr. Kodeksie Panopolitanus, zawierającym fragmenty 1 Hen 1-32, a znalezionym w chrześcijańskim grobie w Akhmim w Górnym Egipcie ${ }^{20}$. W roku 1893 R. H. Charles ukończył i opublikował swoje tłumaczenie, a także komentarz do Księgi Henocha ${ }^{21}$. Charles korzystał z tekstu, który opublikował wcześniej Dillman (1851), ale uwzględnił również dziesięć nowych etiopskich manuskryptów, które były już wówczas dostępne. Właśnie o owych dziesięć manuskryptów było w tamtym czasie bogatsze Muzeum Brytyjskie. Osiem lat później (w 1901 r.), Johannes Flemming (etiopista) oraz Ludwig Radermacher (filolog klasyczny) przygotowali

${ }_{18}$ Por. M.A. Knibb, The Ethiopic Book of Enoch, t. II, 1; A.Y. Collins, From the Ashes of Angels. The Forbidden Legacy of a Fallen Race, Rochester 1996, s. 21.

${ }_{19}$ Por. G. W. E. Nickelsburg, 1 Enoch 1. A Commentary on the Book of 1 Enoch: Chapters 1-36; 81-108, Hermeneia - A Critical and Historical Commentary on the Bible, Minneapolis 2001, s. 109.

${ }^{20}$ Por. J.A. Fitzmyer, "Implications of the New Enoch Literature from Qumran", TS 38 (1977), s. 332-345 [339]. K. Coblentz Bautch, What Becomes of the Angels' 'Wives'? A Text-Critical Study of 1 Enoch 19:2, JBL 125 (2006) 766-780 [767], szacuje okres powstania Kodeksu Panopolitanus na IV lub V wiek po Chr. W roku 1970 Matthew Black we współpracy z A.M. Denis opublikował pierwsze obszerne wydanie dostępnych tekstów greckich Księgi Henocha, zawierające Kodeks Panopolitanus, wyciągi z dzieła Syncellusa, papirus Chester Beaty XII (rozdz. 97-107) oraz fragment Apokalipsy Zwierzęcej (Apocalypsis Henochi Graece [PVTG 3; Leiden 1970]).

${ }^{21}$ Por. R.H. Charles, The Book of Enoch Translated from Professor Dillman's Ethiopic Text, Oxford 1893. 
nowe, niemieckie tłumaczenie $\mathrm{w}$ oparciu o dwadzieścia pięć etiopskich manuskryptów oraz o Kodeks Panopolitanus ${ }^{22}$.

Jednocześnie, Charles wciąż pracował nad nową publikacją. Ostatecznie, w roku 1906, opublikował eklektyczny tekst Księgi Henocha wraz z aparatem krytycznym w oparciu o dwadzieścia dziewięć manuskryptów etiopskich oraz Kodeks Panopolitanus, a także fragmenty z Syncellusa. Na kanwie tego tekstu, w roku 1912, powstał także jego nowy komentarz do Księgi ${ }^{23}$.

Odkrycia zwojów znad Morza Martwego, przypadające na przełom lat 40. i 50. ubiegłego stulecia, stworzyły sytuację bezprecedensową. W grocie 4 nieopodal Qumran odkryto, m.in., jedenaście aramejskich manuskryptów pochodzących z Corpus Henochicum ${ }^{24}$. Siedem z nich zawiera fragmenty Księgi Czuwających (4QEn ${ }^{\mathrm{a}}$ ar [4Q201]; 4QEn ${ }^{\mathrm{b}}$ ar [4Q202]; 4QEnc ar [4Q204]; 4QEne ar [4Q206]), Księgi Snów (4QEn ${ }^{\mathrm{d}}$ ar [4Q205]; 4QEne ar [4Q206]; 4QEn ${ }^{\mathrm{f}}$ ar [4Q207]) oraz Listu Henocha (4QEnc ar [4Q204];

${ }^{22}$ Por. J. Flemming, L. Radermacher, Das Buch Henoch: Herausgegeben im Auftrage der Kirchenväter-Commission der Königlich Preussischen Akademie der Wissenschaften, Leipzig 1901.

${ }^{23}$ Por. G.W.E. Nickelsburg, 1 Enoch 1, s. 111-112;. E. Isaac, New Light Upon the Book of Enoch From Newly-Found Ethiopic MSS, JAOS 103 (1983), s. 399-411 [399], zauważa, że na przełomie XIX i XX wieku, wiedziano już na Zachodzie o dwudziestu dziewięciu manuskryptach etiopskiej wersji Księgi Henocha: 15 w Anglii, 8 we Francji, 4 w Niemczech, 1 we Włoszech oraz 1 w Stanach Zjednoczonych. W roku 1983 badacze dysponowali już jednak ponad sześćdziesięcioma manuskryptami.

${ }^{24}$ Na temat fragmentarycznych tekstów Henocha zobacz na przykład: K. Beyer, Die aramäischen Texte vom Toten Meer samt den Inschriften aus Palästina, dem Testament Levis aus der Kairoer Genisa, der Fastenrolle und den alten talmudischen Zitaten, Göttingen 1984, s. 225-241. J. R. Davila, (How) Can We Tell if a Greek Apocryphon or Pseudepigraphon has been Translated from Hebrew or Aramaic?, 10, zauważa, że niektórzy badacze przekonują, że wśród greckich fragmentów tekstów znalezionych w grocie 7 są także takie, które zawierają tłumaczenia fragmentów Listu Henocha. Autor przedstawia następnie pokrótce nazwiska głównych przedstawicieli tego nurtu. G.W. Nebe, jako pierwszy zidentyfikował $\mathrm{w}$ tekstach pochodzących z groty 7 materiał pochodzący rzekomo z Księgi Henocha (7Q4 - Moglichkeit und Grenze einer Identifikation, RevQ 13 [1988], s. 629-33). Następnie E. Puech przekonywał o słuszności takiej identyfikacji (Notes sur les fragments grecs $d u$ manuscrit 7Q4 = 1 Hénoch 103 et 105, RB 103 [1996], s. 592-600; Sept fragments grecs de la Lettre d'Hénoch [1 Hén 100,103 et 105] dans la grotte 7 de Qumran [= 7Qhéngr], RevQ 18 [1998], s. 313-323). Wreszcie z głosem poparcia dołączył E.A. Munro, Jr (The Greek Fragments of Enoch from Qumran Cave 7 [7Q4, 7Q8, \& 7Q12 = 7QEngr = Enoch 103.3-4, 7-8], RevQ 18 [1998] 307-312). Jednak fragmenty, o których mowa, są bardzo małe i nie wszyscy komentatorzy są przekonani co do prawdziwości przedstawionej powyżej tezy. Zob. również S. Uhlig, Das äthiopische Henochbuch, Gütersloh 1984, 466-780 [479-482]). 
4QEn ${ }^{g}$ ar [4Q212]). Cztery pozostałe zawierają materiał z Księgi Astronomicznej (4QEnastra-d ar [odp. 4Q208-211]). Oprócz tych aramejskich tekstów znaleziono również trzy hebrajskie fragmenty Henocha zawierające teksty 1 Hen 8,4-9,4; 10625. Co ciekawe, pośród znalezionych zwojów nie znaleziono żadnych fragmentów Księgi Przypowieści (1 Hen 37-71). To z kolei ożywiło debatę nad jej ewentualną chrześcijańską proweniencją ${ }^{26}$.

Wielkim impulsem do pogłębionego studium nad omawianą literaturą stały się publikacje J.T. Milika. Jemu to właśnie powierzono fragmentaryczne manuskrypty zidentyfikowane, jako należące do Corpus Henochicum, a znalezione pośród zwojów znad Morza Martwego ${ }^{27}$. Nickelsburg mówi o wielkim szacunku, jaki zdobył sobie Milik wśród komentatorów swoją pracą nad tymi fragmentami. Wspomina jednak również o zastrzeżeniach, które były często wysuwane pod adresem jego pracy. Dotyczyły one na przykład dość obszernych rekonstrukcji, jakich podejmował się Milik. W przedstawionym przez niego tekście, trudno było odróżnić to, co stanowiło zachowany tekst, od tekstu przez niego zrekonstruowanego. Treść owych rekonstrukcji była nierzadko poddawana w wątpliwość. Ponadto Milik miał reprezentować dość niekonsekwentne podejście do etiopskiej wersji Księgi. Z jednej strony bowiem, dość pospiesznie podważał możliwość polegania na tekście etiopskim, jako wiarygodnym świadku wobec oryginalnego tekstu. Z drugiej jednak strony, w praktyce, często używał tekstu etiopskiego, jako podstawy dla wielu swych rekonstrukcji ${ }^{28}$.

${ }_{25}$ Por. M.A. Knibb, Christian Adoption and Transmission of Jezwish Pseudepigrapha: the Case of 1 Enoch, s. 400.

${ }^{26}$ Por. J.C. VanderKam, 1 Enoch, Enochic Motifs, and Enoch in Early Christian Literature, s. 33.

${ }^{27}$ Rezultaty swych badań $\mathrm{w}$ tej materii opublikował Milik w dwóch ważnych artykułach: Problèmes de littérature hénochique à la lumière des fragments araméens de Qumrân, HTR 64 (1971), s. 333-378 oraz Turfan et Qumrân. Livre des Géants juif et manichéen, w: G. Jeremias, H.W. Kuhn, H. Stegemann (red.), Tradition und Glaube: das frühe Christentum in seiner Umwelt. Festgabe für Karl Georg Kuhn zum 65. Geburtstag, Göttingen 1971, s. 117-127.

${ }^{28}$ Por. Nickelsburg, The Books of Enoch in Recent Research, RelSRev 7 (1981), s. 210-211. P. Piovanelli, Il Testo e le Traduzioni dell'Enoch Etiopico 1976-1987, Hen 10 (1988), s. 85-95, wymienia cztery istniejące już pod koniec lat 80. wydania krytyczne Księgi Henocha przedłożone przez następujących autorów: A. Dillmann (1851), J. Flemming (1902), R. H. Charles (1906) i M.A. Knibb (1978). Wreszcie warto wspomnieć również tłumaczenie i komentarz przygotowany przez M. Blacka (The Book of Enoch or 1 Enoch: A New English Edition with Commentary and Textual Notes in Consultation with James 


\section{KWESTIA VORLAGE}

Badacze są zgodni, co do faktu, że odnalezione manuskrypty etiopskie, greckie, a także łacińskie Księgi Henocha były tłumaczeniami $\mathrm{z}$ oryginału, który powstał w jakimś języku semickim ${ }^{29}$. Przez długi czas dyskutowano, o jaki język semicki chodzi. Wśród zgłoszonych propozycji zarysowały się trzy możliwe scenariusze: język hebrajski, aramejski albo w części hebrajski i w części aramejski (tak jak na przykład w przypadku Księgi Daniela) ${ }^{30}$. J.A. Fitzmyer zauważa, że zdecydowane rozstrzygnięcie na korzyść któregoś z tych rozwiązań jest o tyle trudne, że Corpus Henochicum jest produktem długiego procesu redakcyjnego. Obecnie jednak przyjmuje się, że ten proces musiał się rozpocząć od aramejskiego oryginału, który zapewne różnił się znacząco od znanej nam dziś postaci $1 \mathrm{Hen}^{31}$. Autorzy są również zgodni co do tego, że grecka wersja tekstu Księgi jest tłumaczeniem $\mathrm{z}$ aramejskiego ${ }^{32}$.

Corpus Henochicum zachowało się w całości jedynie w klasycznym języku etiopskim - Ge'ez ${ }^{33}$. Tu też długo nie było jednomyślności wśród badaczy w kwestii tego, w oparciu o jaką wersję językową dzieła dokonano przekładu na język etiopski. Dziś jednak raczej powszechnie przyjmuje

C. VanderKam, Leiden Brill 1985). P. Piovanelli, Il Testo e le Traduzioni dell'Enoch Etiopico 1976-1987, 94, nie jest jednak usatysfakcjonowany ich poziomem i postuluje powstanie wydania, które będzie w pełni krytyczne.

${ }^{29}$ Por. np.: G. E. Ladd, The Kingdom of God in the Jewish Apocryphal Literature, s. 328 .

${ }^{30}$ Zob. przegląd propozycji w tym względzie w: S. Uhlig, Das äthiopische Henochbuch, s. 483-484.

${ }^{31}$ Por. J.A. Fitzmyer, Implications of the New Enoch Literature from Qumran, s. 332; I. Fröhlich, Enoch and Jubilees, w: G. Boccaccini (red.), Enoch and Qumran Origins. New Light on a forgotten Connection, Grand Rapids-Cambridge 2005, s. 141-147 [141]: "Qumran Enochic manuscript fragments revealed that the original language of the work was Aramaic". M.J. Davidson, Angels at Qumran. A Comparative Study of 1 Enoch 1-36, 72-108 and Sectarian Writings from Qumran, s. 19, stwierdza: „It is now virtually certain that the language - with perhaps some small exceptions in Hebrew - was Aramaic". O problemach, z jakimi borykają się lingwiści, identyfikując teksty i ich Vorlage zob. J.R. Davila, (How) Can We Tell if a Greek Apocryphon or Pseudepigraphon has been Translated from Hebrew or Aramaic?, 3-61.

${ }^{32}$ Por. K. Coblentz Bautch, What Becomes of the Angels' 'Wives?' A Text-Critical Study of 1 Enoch 19:2, s. 767; G.W. Nickelsburg, The Books of Enoch in Recent Research, s. 210.

${ }^{33}$ Por. M.J. Davidson, Angels at Qumran. A Comparative Study of 1 Enoch 1-36, 72-108 and Sectarian Writings from Qumran, s. 19. 
się, że bazą tekstualną dla tego tłumaczenia była jakaś grecka kopia ${ }^{34}$. Jak już wspomniałem wyżej, proces tłumaczenia na język etiopski ksiąg Pisma świętego, a wraz z nimi i Księgi Henocha został zapoczątkowany najprawdopodobniej w połowie czwartego wieku po Chr. Nastąpiło to po tym, jak chrześcijaństwo zostało uznane za oficjalną religię Królestwa Aksum $^{35}$.

\section{DATACJA}

W roku 1981, Nickelsburg pisał o zmieniających się tendencjach wśród badaczy Księgi Henocha. Według niego, od kwestii czysto literackich nastąpił zwrot $\mathrm{ku}$ problemom związanym $\mathrm{z}$ umiejscowieniem poszczególnych części 1 Hen w czasie oraz w kontekście społeczno-kulturowym $^{36}$. W niniejszym podrozdziale zajmę się pokrótce zagadnieniami datacji i środowiska, w którym powstało omawiane dzieło. Problem jest o tyle skomplikowany, że mamy tu do czynienia z więcej niż jedną księgą i więcej niż jednym autorem. Co gorsza, dysponujemy dziś wieloma różnymi manuskryptami i odpisami, które nie sprawiają wrażenia pochodzących z jednego źródła. Ponadto trzeba jeszcze uwzględnić fakt, że poszczególne części Księgi Henocha powstały w różnym czasie i przez pewien czas żyły własnym życiem - jako niezależne księgi. Nie umiemy powiedzieć, kto i kiedy dokonał ostatecznej redakcji Księgi oraz dla jakich powodów ${ }^{37}$.

W obliczu takich faktów, niektórzy badacze wolą pominąć kwestie datacji milczeniem. Najlepszym przykładem jest tu M. Knibb, który we

${ }^{34}$ Por. K. Coblentz Bautch, What Becomes of the Angels' 'Wives'?, s. 767-768; M.A. Knibb, The Ethiopic Book of Enoch, t. II, s. 37-38, twierdzi, że założenie, iż etiopski tekst Henocha jest tłumaczeniem z greki, jest tak powszechne, że większość badaczy uznała tę sprawę za niewartą dalszej dyskusji. Według jego wiedzy (Knibba), ten pogląd został podważony jedynie dwa razy, przez Schmidta oraz Ullendorffa. Schmidt optował za tym, że oryginalnym językiem Księgi Przypowieści był aramejski, a także, że Księga Przypowieści została przetłumaczona na etiopski bezpośrednio z aramejskiego. Później Ullendorff przekonywał, że nie tylko Księga Przypowieści, ale większa cześć Henocha zostały przetłumaczone $\mathrm{z}$ aramejskiego na etiopski.

${ }_{35}$ Por. M. A. Knibb, Christian Adoption and Transmission of Jewish Pseudepigrapha: The Case of 1 Enoch, JSJ 32 (2001), s. 396-415 [413].

${ }^{36}$ Por. G.W.E. Nickelsburg, The Books of Enoch in Recent Research, s. 212.

${ }^{37}$ Por. G.E. Ladd, The Kingdom of God in the Jewish Apocryphal Literature, s. 327. 
wstępie do swojego komentarza, w ogóle nie zajmuje się kwestią datacji. Inni komentatorzy skupiają się raczej na próbach określenia czasu wyłonienia się tradycji henochickich, których omawiane księgi są produktem. Podobne rozważania będą już zawsze musiały pozostać na poziomie hipotez. Warto, jednak, zauważyć pewną ewolucję w poglądach, gdy chodzi o kwestię przypuszczalnej datacji.

W XIX wieku nie brakowało badaczy, którzy chcieli widzieć w Księdze Henocha dzieło chrześcijańskie, ze względu na narzucające się podobieństwa z chrześcijańską doktryną eschatologiczną. Chodzi tu zwłaszcza o doktrynę o Synu Człowieczym, który jest prominentną postacią w Księdze Przypowieści (1 Hen 37-71) ${ }^{38}$. W pierwszej połowie XX wieku sądzono, iż Księgi Henocha reprezentowały nurt apokaliptyczny w łonie judaizmu, którego powstanie należało umiejscowić pomiędzy rokiem 150 a 100 przed Chr. Decydującym impulsem dla jego rozwoju miała być rewolta Machabeuszy ${ }^{39}$. Autorzy, którzy reprezentowali podobne poglądy, podpierali je nieraz dość misternie utkaną argumentacją ${ }^{40}$.

${ }^{38}$ Por. np.: J. Drummond, The Jewish Messiah, London 1877, s. 49-73; H. Stanton, The Jewish and the Christian Messiah, Edinburgh 1886, s. 62-63.

${ }^{39}$ Por. H.S. Kvanvig, The Watcher Story and Genesis. Intertextual Reading, SJOT 18 (2004), s. 163-183 [166]. Zob. także H.S. Kvanvig, Gen 6,3 and the Watcher Story, Hen 25 (2003), s. 277-300 [277].

${ }^{40}$ Dobrym przykładem jest tu G. E. Ladd (The Kingdom of God in the Jewish Apocryphal Literature, s. 329-330), który wyszedł od obserwacji, że na przykład w Testamencie Dwunastu Patriarchów, który powstał po czasach Jana Hirkana (135-104 przed Chr.), znajduje się dziewięć bezpośrednich odniesień do Henocha. Jednak jedynie trzy $\mathrm{z}$ nich znajdują paralele $\mathrm{w}$ znanym nam tekście 1 Hen. Według autora oznacza to, że około roku 100 przed Chr. istniały także inne, prawdopodobnie również spisane, tradycje związane z postacią Henocha. Kolejne odniesienie chronologiczne dostrzegalne jest w samym tekście 1 Hen. Otóż w Księdze Przypowieści (1 Hen 56:5), aniołowie sprowadzają sąd Boży na nieprzyjaciół Żydów na Wschodzie, czyli na Partów i Medów. Przed rokiem 100 przed Chr. wielkim wrogiem Żydów była Syria, a po inwazji Pompejusza w roku 64 przed Chr. był nim Rzym. W czasie, pomiędzy jedną a drugą datą, najgroźniejszym pogańskim i wrogim ludem na Wschodzie byli Partowie. Zatem Księga Henocha - według Ladda - odzwierciedla stan ducha narodu żydowskiego tego właśnie okresu. Wreszcie, Ladd nawiązuje do treści drugiej Wizji Sennej (1 Hen 85-90), gdzie przy pomocy wielu symboli przedstawiona jest historia świata od Adama do ustanowienia Królestwa Mesjańskiego. Można tam rozpoznać niewolę babilońską, okresy perski i grecki, aż do powstania Machabeuszy przeciwko Antiochowi Epifanesowi oraz być może nawet - nawiązanie do wydarzeń, które bezpośrednio nastąpiły pod rządami Hasmoneuszów. Według Ladda wynika stąd, że datacja tej części musi przypadać na lata następujące po 168 r. przed Chr., ale przed nadejściem Rzymian w 64 przed Chr. Ostatecznie, wszystkie powyższe obserwacje skłoniły go do wysunięcia tezy, że księgi 
Z pewnością punktem przełomowym, gdy chodzi o datację, były wspomniane już odkrycia w Qumran. Na początku września 1952 roku, Milik zidentyfikował pierwsze aramejskie fragmenty Henocha pomiędzy manuskryptami znalezionymi w grotach nad Morzem Martwym. Zbiór większości aramejskich fragmentów Henocha został opublikowany przez niego w 1976. Okazało się, że najstarsze spośród tych pism musiały pochodzić z okresu o wiele wcześniejszego niż uprzednio sądzono. Sam Milik szacował ich powstanie na okres od wczesnego wieku drugiego przed Chr. do około roku 50 przed Chr. Według niego, wszystko wskazuje na to, iż tuż przed rozpoczęciem ery chrześcijańskiej, istniał w Qumran „Pięcioksiąg Henochicki”, który z grubsza odpowiadałby dzisiejszej kompozycji 1 Hen, z tym że w miejscu Księgi Przypowieści była tam Księga Gigantów ${ }^{41}$. Teoria o istnieniu „Pięcioksięgu Henochickiego" nie zyskała jednak szerokiej akceptacji wśród badaczy.

Według J. H. Charlesworth'a, z paleograficznego studium aramejskich fragmentów Księgi Henocha można wyciągnąć dwa ważne wnioski. Po pierwsze, księgi składowe Corpus Henochicum, których są częściami, muszą pochodzić sprzed roku 200 przed Chr. Po drugie, jest raczej pewne, że księgi te nie powstały w Qumran. Tak więc, data ich powstania musi być wcześniejsza niż zamieszkanie wspólnoty w Qumran ${ }^{42}$.

W podobnym tonie wypowiada się S. Uhlig, chociaż nieco inaczej rozkłada akcenty. Według niego, datacja paleograficzna najstarszego aramejskiego dokumentu (4QEn ${ }^{\mathrm{a}}$ ar) dowodzi niezbicie jego „przedmachabejskiego" pochodzenia. Co więcej, twierdzi on, że ów dokument, razem z 4QEn ${ }^{\mathrm{b}}$ ar wskazują, że dzieło nazwane przez Syncellusa „Księgą

wchodzące w skład Corpus Henochicum należy umiejscowić w czasie pomiędzy rokiem 165 a 64 przed Chr. Jednocześnie zaznaczył on, że nie można wykluczyć, iż ostateczna kompilacja zbioru nastąpiła w późniejszym czasie

Warto zauważyć, że gdy chodzi o wiek tradycji henochickich, to C. A. Evans, Noncanonical Writings and New Testament Interpretation, Peabody 1992, s. 23), ustala je na okres 200 przed Chr. do 50 po Chr. Podobnie S. Mędala, Wprowadzenie do Literatury Międzytestamentalnej, Kraków 1994, s. 133, który mówi tu o okresie „od początku II wieku przed Chr. do połowy I w. po Chr.".

${ }^{41}$ Por. J.T. Milik, Problèmes de la littérature hénochique à la lumière des fragments araméens de Qumran, HTR 64 (1971), s. 333-378 [334]. Por. także J.T. Milik, The Books of Enoch: Aramaic Fragments of Qumran Cave 4, Oxford 1976, s. 24.

${ }^{42}$ Por. J.H. Charlesworth, A Rare Consensus Among Enoch Specialists: the Date of the Earliest Enoch Books, w: G. Boccaccini (red.), The Origins of Enochic Judaism: Proceedings of the First Enoch Seminar, University of Michigan, Sesto Fiorentino, Italy, June 19-23, 2001, Torino 2002, s. 225-234 [232]. 
Czuwających" (1 Hen 1-36), było w obiegu, jako niezależna aramejska kompozycja, już w trzecim wieku przed Chrystusem. Według Uhliga, nie jest to jednak najstarsza część Corpus Henochicum. Pod tym względem, ustępuje ona, bowiem, Księdze Astronomicznej, która była prawdopodobnie znana już kapłańskiemu redaktorowi Pięcioksięgu Mojżesza. Według niego, Księga Czuwających w swej zasadniczej części (1 Hen 6-36), miała powstać, w czwartym wieku przed Chr., o ile nie wcześniej. Trzecią, co do wieku, jest według niego Księga Snów (1 Hen 83-90). Miała ona być „rówieśniczką” Księgi Daniela powstałej ok. 164 r. przed Chr. List Henocha (1 Hen 91-104) powstał prawdopodobnie pod koniec drugiego wieku przed Chr. Osobny problem stanowi Księga Przypowieści. Jak już wspomniałem wyżej nie znaleziono żadnych jej fragmentów wśród manuskryptów z Qumran. Według Uhliga księga ta została napisana pod koniec pierwszego wieku po Chr. i ostatecznie zajęła miejsce tzw. Księgi Gigantów ${ }^{43}$.

Również T. Beckwith uważał, że odkrycia w Qumran rzuciły zupełnie nowe światło na kwestie pochodzenia i datacji Księgi Henocha. Autor wyszedł od założenia, że skoro Qumran było siedzibą Esseńczyków, to księgi, o których mowa są najprawdopodobniej pochodzenia esseńskiego lub pre-esseńskiego ${ }^{44}$. W celu ustalenia daty ich powstania postulował odwołanie się do danych językowych. Chodziło mianowicie o ustalenie, jakie stadium rozwoju języka aramejskiego reprezentowały fragmenty literatury henochickiej z Qumran. Sam jednak przyznawał, że istnieje bardzo mało literatury aramejskiej z tego okresu, która mogłaby być punktem odniesienia dla takich porównań. Ponadto, potoczny język aramejski jest również słabo udokumentowany. Zatem argumenty lingwistyczne w kwestiach dotyczących datacji, mogą być używane jedynie z wielką ostrożnością. Należy pamiętać, że autorzy mogli na przykład celowo archaizować, tzn. stylizować swe pisma na starsze niż faktycznie były. Z drugiej strony, kopiści mogli dokonywać zgoła odmiennego zabiegu - uwspółcześniać stare pisma. Dlatego Beckwith dochodzi do wniosku, że pewniejszych wskazówek odnośnie do datacji poszczególnych ksiąg należy raczej szukać w samej ich treści. Według niego, Księga Snów oraz List Henocha czynią wyraźne odniesienia do powstania ruchu esseńskiego oraz wyzwoleńczego powstania machabejskiego (1 Hen 90:9-10; 93:9-10;

${ }^{43}$ Por. S. Uhlig, Das äthiopische Henochbuch, s. 142.

${ }^{44}$ Por. R.T. Beckwith, The Earliest Enoch Literature and its Calendar: Marks of Their Origin, Date and Motivation, RevQ 39 (1981), s. 365-403 [365]. 
91:11). Jeśli przyjmiemy, że owe wzmianki nie są przepowiedniami, to sytuują one kompozycję Księgi Snów oraz Listu Henocha w okresie po roku 167 przed Chr. Księga Astronomiczna oraz Księga Czuwajacych nie czynią żadnych wzmianek w tym względzie. Sądząc po, zwłaszcza, pierwszej i drugiej kategorii wzmianek wydaje się jasnym, że Księga Astronomiczna oraz Ksiega Czuwających są najwcześniejszymi z owych czterech ksiąg. Ich powstanie należy przesunąć na okres przed powstaniem ruchu esseńskiego, jako oddzielnej i zorganizowanej grupy, co mogło nastąpić około roku 171 przed Chr., czyli tuż przed rewoltą Machabeuszów. Zatem kompozycję Ksiąg Astronomicznej i Czuwających należałoby umieszczać prawdopodobnie w okresie około lub przed końcem trzeciego wieku przed Chrystusem ${ }^{45}$.

W latach 90. wciąż nie było jednomyślności w kwestii datacji poszczególnych ksiąg Corpus Henochicum. Nie mniej jednak pojawiły się poglądy o bardzo wczesnym datowaniu najstarszych części Księgi Henocha. Na przykład P. Sacchi twierdził, że rozdziały 6-11 oraz 12-36 pochodzą z okresu od piątego do trzeciego wieku przed Chrystusem ${ }^{46}$. G.W.E. Nickelsburg uważał, że 1 Hen powstawał pomiędzy końcem wieku czwartego przed Chr., a przełomem milleniów ${ }^{47}$. G.S. Oegema, powołując się na innych badaczy, mówił o reprezentowanym przez nich poglądzie, że literatura henochicka mogła się narodzić w trzecim stuleciu przed Chr. Za najstarsze uznał dwa fragmenty 1 Hen 6-16 oraz 1 Hen 17-36. Od drugiego stulecia zbiór ten miał być systematycznie powiększany ${ }^{48}$.

Wreszcie, w czasie sympozjum poświęconego w całości Księdze Henocha, które odbyło się we Florencji (w czerwcu 2001 r.), nastąpił nieoczekiwany przełom $\mathrm{w}$ kwestii opinii na temat datacji literatury henochickiej. Po żarliwej dyskusji eksperci, jednogłośnie zgodzili się, że literatura, o której mowa, została zapoczątkowana przed rokiem 200 przed Chr. Co więcej, ustalono, że na jakimś etapie pomiędzy rokiem 300 i 200 przed Chr., w starożytnej Palestynie, grupa uczonych Żydów rozpoczęła pisanie

45 Por. R.T. Beckwith, The Earliest Enoch Literature and its Calendar: Marks of Their Origin, Date and Motivation, s. 365-367.

${ }^{46}$ Por. P. Sacchi, Jewish Apocalyptic and its History, Sheffield 1990, s. 61-71.

47 Por. G.W. E. Nickelsburg, Enochic Wisdom: An Alternative to the Mosaic Torah, w: J. Magness, S. Gittin (red.), HESED VE-EMET. Studies in Honor of Ernest S. Frerichs, Atlanta 1998, s. 123-132 [124].

${ }^{48}$ Por. G.S. Oegema, Apokalypsen, Gütersloh 2001, s. 132. 
tego, co dziś znamy, jako Księge Astronomiczna oraz Księge Czuwajacych. Tym samym, okres powstania najwcześniejszych kompozycji henochickich został zawężony do około stu lat - pomiędzy 300 a 200 przed Chr. ${ }^{49}$

\section{PODSUMOWANIE}

Księga Henocha to niewątpliwie dzieło kontrowersyjne z punktu widzenia wielu żydów ery przedchrześcijańskiej, jak i chrześcijan kilku pierwszych wieków. Podczas, gdy w łonie jednej i drugiej grupy byli zagorzali zwolennicy Corpus Henochicum, to nie brakowało i takich, którzy odrzucali je jako szkodliwe i nieużyteczne z punktu widzenia wiary. Księga, o której mowa, jest zapisem różnych tradycji apokaliptycznych - często niezbyt spójnych - które wyrosły w łonie judaizmu Drugiej Świątyni. Dzięki studium takich dzieł pośrednio zyskujemy dostęp do bogactwa myśli i prądów teologicznych obecnych w łonie judaizmu biblijnego. Jednym z wniosków, które od razu się narzucają jest ten, że ów judaizm nie był bynajmniej monolitem. To z kolei daje szerszy obraz na kontekst, w jakim żył i nauczał Jezus, a także narodziło się chrześcijaństwo.

Powyższy artykuł był próbą pokazania, że Księga Henocha, poza swym walorem treściowym, jest również fascynująca pod względem historii kompozycji, tłumaczeń i transmisji. Okazuje się, że dzieło to miało swe poczytne miejsce wśród zwojów znalezionych w Qumran, było często cytowane i powoływano się na nie w pismach pisarzy wczesnochrześcijańskich, a w późniejszych epokach zaznaczyło się coś w rodzaju "gorączki Henocha" czyli ekscytujące poszukiwania starożytnych odpisów Księgi. Po długiej przerwie wśród współczesnych autorów znowu zaznacza się trend w kierunku studium Księgi Henocha. Jest ono o tyle łatwiejsze, że dysponujemy już krytycznymi wydaniami dzieła. Od kilkunastu lat uczeni są raczej zgodni w kwestii datacji Corpus Henochicum. Jednak ten fakt należy raczej potraktować jako swoisty wyjątek w toczącej się wciąż dyskusji o roli, wpływie, teologii i znaczeniu Księgi.

${ }^{49}$ J.H. Charlesworth, A Rare Consensus Among Enoch Specialists: the Date of the Earliest Enoch Books, s. 234. 
Streszczenie. Księga Henocha (Corpus Henochicum lub 1 Hen) jest prawdopodobnie najstarszym i najważniejszym żydowskim apokryfem. Składa się z pięciu różnych segmentów (ksiąg) oraz załącznika datowanych na III w. p.n.e. Mimo, że księga ta nie znalazła miejsca ani w kanonie żydowskim ani chrześcijańskim, cieszyła się ona dużym uznaniem tak ze strony Żydów okresu drugiej Świątyni, jak i wczesnych chrześcijan. W rzeczywistości musiała ona mieć wielki wpływ na przedchrześcijański judaizm, jak również na samo chrześcijaństwo, głównie na polu apokaliptycyzmu. Ostatnio badacze zaczynają doceniać bardziej niż kiedykolwiek znaczenie tego dzieła w kontekście studiów nad judaizmem okresu drugiej Światyni. Może ona okazać się wyjątkowo pomocna w rzuceniu nowego światła na proces rozwoju pewnych teologicznych idei, kluczowych dla judaizmu i chrześcijaństwa. Niniejszy artykuł jest przeglądem współczesnej wiedzy do tyczącej historii kompozycji i transmisji Corpus Henochicum, jak również zagadnienia Vorlage i datacji jego najstarszych części.

Słowa kluczowe: apokryf; starożytność; Henoch; współczesna wiedza.

Abstract. The Book of Enoch - an ancient apocryphon in the light of modern knowledge. The Book of Enoch (Corpus Henochicum or $1 \mathrm{Hen}$ ), is the oldest and probably the most important Jewish apocryphal work. It consists of five different segments (books) and an appendix dating from various times in the third century B.C. Even though the Book did not make its way to the Hebrew or Christian canon, it was highly respected by many Second Temple Jews and early Christians. Actually it must have had a great impact on pre-Christian Judaism, as well as on Christianity - especially in the field of apocalypticism. Nowadays, scholars tend to appreciate more than ever the importance of the work for the study of the Second Temple Judaism. It can especially be helpful in shedding more light on the process of development of some theological ideas crucial for Judaism and Christianity. The current paper is a survey of contemporary knowledge concerning the history of composition and transmission of the Corpus Henochicum, as well as the question of the Vorlage and of the date of its earliest parts.

Keywords: apocryph; ancient culture; Enoch; modern knowledge. 
